\title{
The threat of root-knot nematodes (Meloidogyne spp.) in Africa: a review
}

\author{
E. M. Onkendi ${ }^{1}$, G. M. Kariuki², M. Marais ${ }^{3}$ and L. N. Moleleki ${ }^{{ }^{\star}}$
}

E. M. Onkendi 1

Forestry Agriculture and Biotechnology Institute (FABI)

Department of Microbiology and Plant Pathology

University of Pretoria

South Africa

Email: eddy.onkendi@fabi.up.ac.za

G. M. Kariuki²

Department of Agricultural Sciences and Technology

Kenyatta University

Kenya

Email: gmmkariuki@yahoo.com

M. Marais ${ }^{3}$

National Collection of Nematodes

Biosystematics Division

Agricultural Research Council-Plant Protection Research Institute (ARC-PPRI)

Private bag $\mathrm{X} 134$

Queenswood, 012a

South Africa

Email: maraisM@arc.agric.za

L. N. Moleleki ${ }^{1 *}$

Forestry Agriculture and Biotechnology Institute (FABI)

Department of Microbiology and Plant Pathology 
University of Pretoria

South Africa

Tel: +27(0)124204662

Fax: +27(0)12 4203688

Email: lucy.moleleki@up.ac.za

Corresponding Author: Email: lucy.moleleki@up.ac.za

\section{Abstract}

Meloidogyne species pose a significant threat to crop production in Africa due to the losses they cause on a wide range of agricultural crops. The direct and indirect damage caused by various Meloidogyne species results in delayed maturity, toppling, reduced yields and quality of crop produce, high costs of production and therefore loss of income. In addition, emergence of resistance-breaking Meloidogyne species has partly rendered various pest management programmes already in place ineffective therefore putting food security of the continent at risk. It is likely that more losses may be experienced in the future due to the on-going withdrawal of nematicides. To adequately address the threat of Meloidogyne species in Africa, an accurate assessment and understanding of the species present, genetic diversity, population structure, parasitism mechanisms and how each of these factors contribute to the overall threat posed by Meloidogyne species is important. Thus, the ability to accurately characterise and identify Meloidogyne species is crucial if we are to effectively tackle the threat of Meloidogyne species to crop production in Africa. In this review, we discuss the use of traditional versus molecular-based identification methods of Meloidogyne species and how accurate identification using a polyphasic approach can negate the eminent threat of root knot nematodes in crop production. The potential threat to Africa posed by highly damaging and resistance-breaking populations of 'emerging' Meloidogyne species is also examined.

Key words: Meloidogyne, identification, resistance-breaking, economic impact, pest management. 


\section{Introduction}

In the recent past, the usage of nematicides has led to a significant reduction of Meloidogyne spp. populations in crop production. However, due to their toxicity and adverse effects on the environment, many nematicides have been or are currently being withdrawn from the market. This has now propelled Meloidogyne spp. to the forefront as important pathogens of many crops and other plants. In fact, in a 2013 Molecular Plant Pathology survey of the top ten plant parasitic nematodes, Meloidogyne spp. collectively were voted at the top of the list (Jones et al., 2013). In this article, we assess the current threat of Meloidogyne spp. to crop production with a specific focus on Africa. We also discuss the importance of an integrated approach towards accurate species identification and current as well as future Meloidogyne spp. management strategies.

\section{Meloidogyne species present in Africa}

There are currently nearly 100 recognised Meloidogyne spp., with 22 of these species reported to be present in Africa (Table 1). Historically, Meloidogyne spp. have been divided into major and emerging species. According to Moens et al. (2009), M. arenaria, M. incognita, M. javanica (occurring in tropical regions) and $M$. hapla (occurring in temperate regions) are considered to be the four major Meloidogyne spp. However, these authors consider a further five species as emerging species. These five emerging species are: Meloidogyne chitwoodi, M. fallax, M. enterolobii, M. minor and $M$. paranaensis. In Africa, Meloidogyne arenaria, M. javanica and M. incognita are regarded as the most dominant species reported in 26,36 and 37 different cofig

untries across the continent, respectively (IITA, 1981; De Waele and Elsen, 2007). Collectively, these three species have been reported to cause damage in economically important crop plants such as sweet potato, banana, tomato, cabbage, potatoes, pineapple, cassava, maize, tobacco, cowpea as well as others such okra (Abelmoschus esculentus), papaya, buchu (Agathosma betulina), African spinach, (for a full list of hosts refer to Table 1). On the other hand, three of the five emerging species, namely M. chitwoodi, $M$. enterolobii and $M$ fallax, are reported from Africa (Table 1). For example, the resistance-breaking apomictic species, $M$. enterolobii has been isolated from Burkina Faso, DRC, Malawi, Mozambique, Senegal, South Africa and Togo causing damage in potatoes and gauva (Marais, 2012; Onkendi and Moleleki, 2013b). On the other hand, M. chitwoodi and M. fallax have been reported to cause damage on Other Meloidogyne spp affecting economically important crop plants in Africa 
Table 1 Meloidogyne species reported from various parts of Africa

\begin{tabular}{|c|c|c|c|}
\hline Meloidogyne sp. & Country/region & Crop(s) affected & References \\
\hline M. acronea & Kenya, South Africa, Malawi & $\begin{array}{l}\text { Cotton, pigeon pea, sorghum, millet, grasses, } \\
\text { pea, bulrush, okra, potato, tomato }\end{array}$ & $\begin{array}{l}\text { Whitehead \& Kariuki } \\
\text { (1960); Hunt \& Handoo } \\
\text { (2009) }\end{array}$ \\
\hline M. africana & Kenya, Sudan, Tanzania & Coffee & $\begin{array}{l}\text { Whitehead (1959); } \\
\text { Eisenback (1997) }\end{array}$ \\
\hline M. arenaria & $\begin{array}{l}\text { Algeria, Cote d'Ivoire, Egypt, Gambia, Ghana, } \\
\text { Liberia, Libya, Madagascar, Malawi, Mauritius, } \\
\text { Morocco, Mozambique, Nigeria, Sao Tome and } \\
\text { Principé, Senegal, South Africa, Sudan, Tanzania, } \\
\text { Uganda, Zimbabwe }\end{array}$ & $\begin{array}{l}\text { Date palm, peach, potato, tobacco, } \\
\text { tea, carrot, tomato, lettuce, cucumber, } \\
\text { aubergine, cotton, soybean, pineapple, } \\
\text { pyrethrum, banana, papaya, pepper, } \\
\text { cowpea, okra, velvet bean }\end{array}$ & IITA (1981); CABI (2003) \\
\hline M. chitwoodi & South Africa, Mozambique & Potato, cassava, groundnut, wheat soil & $\begin{array}{l}\text { Kleynhans et al. (1996); } \\
\text { Fourie et al. (2001b); } \\
\text { Coyne et al. (2006b) }\end{array}$ \\
\hline M. decalineata & Tanzania, Sao Tome & Coffee & $\begin{array}{l}\text { Whitehead (1968); } \\
\text { Lordello \& Fazuoli (1980) }\end{array}$ \\
\hline M. enterolobii & $\begin{array}{l}\text { Malawi, Senegal, South Africa, Cote d'Ivoire, } \\
\text { Burkina Faso, Democratic Republic of Congo }\end{array}$ & Potato, guava & $\begin{array}{l}\text { M. Marais (unpublished } \\
\text { data); Onkendi \& } \\
\text { Moleleki }(2013 a, b)\end{array}$ \\
\hline M. exigua & Mozambique & Cassava & Coyne et al. (2006b) \\
\hline M. ethiopica & $\begin{array}{l}\text { Ethiopia, Mozambique, Tanzania, Zimbabwe, } \\
\text { South Africa }\end{array}$ & $\begin{array}{l}\text { Tomato, bean, black wattle (Acacia mearnsii), } \\
\text { cabbage, tobacco, pumpkin, pepper, } \\
\text { macadamia, pineapple, carrot, home } \\
\text { gardens, natural veld, potato }\end{array}$ & $\begin{array}{l}\text { Whitehead (1968, 1969); } \\
\text { CABI (2005) }\end{array}$ \\
\hline M. fallax & South Africa & Groundnut & Fourie et al. (2001b) \\
\hline M. graminicola & South Africa & Paspalum spp. & Kleynhans (1991) \\
\hline M. hapla & $\begin{array}{l}\text { Algeria, Cote d'Ivoire, Egypt, Kenya, Libya, } \\
\text { Malawi, Morocco, Nigeria, South Africa, } \\
\text { Tanzania, Uganda, Zimbabwe }\end{array}$ & $\begin{array}{l}\text { Potato, date palm, groundnut, } \\
\text { native plants and numerous crops }\end{array}$ & $\begin{array}{l}\text { Fourie et al. (2001b); } \\
\text { CABI (2002a) }\end{array}$ \\
\hline M. hispanica & Burkina Faso, Malawi, South Africa & $\begin{array}{l}\text { Granadilla, sugarcane, Ficus spp., } \\
\text { ornamental crops, grapevine }\end{array}$ & Kleynhans (1991) \\
\hline M. incognita & $\begin{array}{l}\text { Algeria, Angola, Botswana, Burkina Faso, } \\
\text { Cameroon, Congo, Democratic Republic of } \\
\text { Congo, Cote d'Ivoire, Egypt, Ethiopia, } \\
\text { Gambia, Ghana, Guinea, Kenya, Liberia, } \\
\text { Libya, Madagascar, Malawi, Mauritania, } \\
\text { Mauritius, Morocco, Mozambique, Namibia, } \\
\text { Niger, Nigeria, Reunion, Senegal, Seychelles, } \\
\text { Somalia, South Africa, Sudan, Tanzania, } \\
\text { Tunisia, Uganda, Zambia, Zimbabwe }\end{array}$ & $\begin{array}{l}\text { Potato, grapevine, maize, date palm, tomato, } \\
\text { tobacco, cowpea, upland rice, soybean, } \\
\text { papaya, pepper, aubergine, cauliflower, } \\
\text { okra, cabbage, Chinese cabbage, onion, } \\
\text { watermelon, African spinach, coconut, } \\
\text { mango, citrus, guava, yam, cassava } \\
\text { and numerous crops }\end{array}$ & $\begin{array}{l}\text { IITA (1981); CABI } \\
\text { (2002b); Kwerepe \& } \\
\text { Labuschagne (2004); } \\
\text { SAPPNS database }^{a}\end{array}$ \\
\hline M. javanica & $\begin{array}{l}\text { Aldabra, Algeria, Angola, Botswana, Burundi, } \\
\text { Comoros, Democratic Republic of Congo, } \\
\text { Cote d'Ivoire, Egypt, Eritrea, Gabon, Gambia, } \\
\text { Ghana, Kenya, Liberia, Libya, Madagascar, } \\
\text { Malawi, Mauritania, Mauritius, Morocco, } \\
\text { Mozambique, Namibia, Nigeria, Reunion, } \\
\text { Rwanda, Senegal, South Africa, Sudan, } \\
\text { Tanzania, Tunisia, Uganda, Zambia, Zimbabwe }\end{array}$ & $\begin{array}{l}\text { Potato, buchu (Agathosma betulina), } \\
\text { sugarcane, banana, yam, sweet potato, } \\
\text { date palm, tobacco, broad bean, celery, } \\
\text { tomato, upland rice, aubergine, cabbage, } \\
\text { Chinese cabbage, cassava and numerous } \\
\text { crops }\end{array}$ & $\begin{array}{l}\text { IITA (1981); } \\
\text { CABI (2002b); } \\
\text { SAPPNS database }\end{array}$ \\
\hline M. kikuyensis & Kenya, South Africa, Tanzania & Kikuyu grass, sugarcane & $\begin{array}{l}\text { De Grisse (1960); } \\
\text { Kleynhans (1991) }\end{array}$ \\
\hline M. megadora & Angola, Sudan & Coffee, carrot, banana & $\begin{array}{l}\text { Whitehead (1968); } \\
\text { Eisenback (1997) }\end{array}$ \\
\hline M. morocciensis & Morocco & Peach & $\begin{array}{l}\text { Rammah \& Hirschmann } \\
\text { (1990) }\end{array}$ \\
\hline M. naasi & Mozambique & Cassava & Coyne et al. (2006b) \\
\hline M. oteifai & Democratic Republic of Congo & Coffee & Elmiligy (1968) \\
\hline M. partityla & South Africa & Pecan, walnut & Kleynhans (1991) \\
\hline M. propora & Aldabra Atoll & $\begin{array}{l}\text { Black nightshade (Solanum nigrum), } \\
\text { Cyperus obtusiflorus }\end{array}$ & Spaull (1977) \\
\hline M. vandervegtei & South Africa & Unidentified woody plant from coastal forest & Kleynhans et al. (1996) \\
\hline
\end{tabular}

The SAPPNS database was made available courtesy of M. Marais (ARC, South Africa). 
include those that infect coffee ( $M$. africana, $M$. decalineata, M.decalieata and $M$. oteifai); cassava ( $M$. exigua, M. chitwoodi, M. megadora, and $M$.

naasi); sugarcane (M. hispanica and M. kikuyensis) and cotton (M. acronea). A number of Meloidogyne spp have also been reported on trees and woody shrubs such as $M$. ethiopica infecting black wattle (Acacia mearnsii); M. morocciensis infecting peach trees; M. partityla infecting pecan and walnut trees M. propora reported on black night shade (Solanum nigrum) as well as $M$. vandervegtei which has been reported on woody plants and coastal forests. Two Meloidogyne species, M. graminicola and M. kikuyensis have been reported to affect members of the Poaceae family, Paspalum spp and kikuyu (Pennisetum clandestinum) respectively.

The number of Meloidogyne species listed in table 1 is most certainly not exhaustive due to paucity of data in many regions. Because the three major species ( $M$. arenarea, $M$ incognita and $M$. javanica) are widespread and well-studied, this might have led to bias against accurate identification of the emerging species. Consequently, it is possible that many of the species listed as one of the major species could have been incorrectly diagnosed. Hence, it is conceivable that the potential impact of new and emerging species has been grossly understated. Similar problems of misidentified Meloidogyne species have been previously reported. For instance, for many years both M. paranaensis and M. enterolobii were misidentified as M. incognita (Yang et al., 1986; Carneiro et al., 1996). Thus we can anticipate that the wide adoption of molecular diagnostic tools in the future could lead to the number of species increasing as more cases of misidentification are made known or new species are recorded. It is important that the different Meloidogyne species are accurately identified in order to be able to evaluate their impact. It is also important to determine which quarantined Meloidogyne spp. are currently present in Africa and the extent of their distribution. If present, are they being accurately identified? Can we employ new diagnostic tools that are based on molecular technology together with classical methods to carry out accurate identification? For instance, Onkendi and Moleleki, 2013a\&b have recently demonstrated the use of molecular approaches in accurately identifying various Meloidogyne spp. present in potatoes from South Africa. This information will enhance our knowledge of the current population densities and distribution of different Meloidogyne species and guide farmers in the implementation of integrated pest management strategies.

\section{Economic impact}

Meloidogyne spp. cause an estimated annual loss of $\$ 157$ billion globally (Abad et al., 2008). However, in most cases, the impact of Meloidogyne spp. is grossly underestimated. This is more so in 
Africa than anywhere else in the world. Hence it is likely that the overall annual losses due to these pathogens are much higher than estimated. In many crop producing regions in Africa, there has been no comprehensive assessment that focuses specifically on the economic impact of Meloidogyne spp. (Coyne et al., 2006a). There are several factors that have led to the scanty availability of information on the economic impact of Meloidogyne spp. across Africa. Firstly, there is a general lack of awareness of the effect of Meloidogyne spp. in crop production. As a result, these pathogens tend to be overlooked. Secondly, the long-term use of nematicides has led to an underestimated effect of Meloidogyne spp. however, with diminishing options for use of nematicides, Meloidogyne spp. problems are steadily beginning to resurface. Finally, the lack of information can be attributed to the acute lack of resources (both financial and human) to initiate large scale projects necessary to fully assess the Meloidogyne spp. situation in Africa (De Waele and Elsen, 2007). Even though in general there is limited information on the impact of Meloidogyne spp. in crop production in Africa, there is growing evidence that suggests that the problem of Meloidogyne spp. in most farms across the continent is a significant threat to crop production. Furthermore, through several projects, among others the International Meloidogyne Project (IMP), it is evident that Meloidogyne spp. cause considerable damage to various crops (Figure 1) (Jones, 2005; Coyne et al., 2006b).
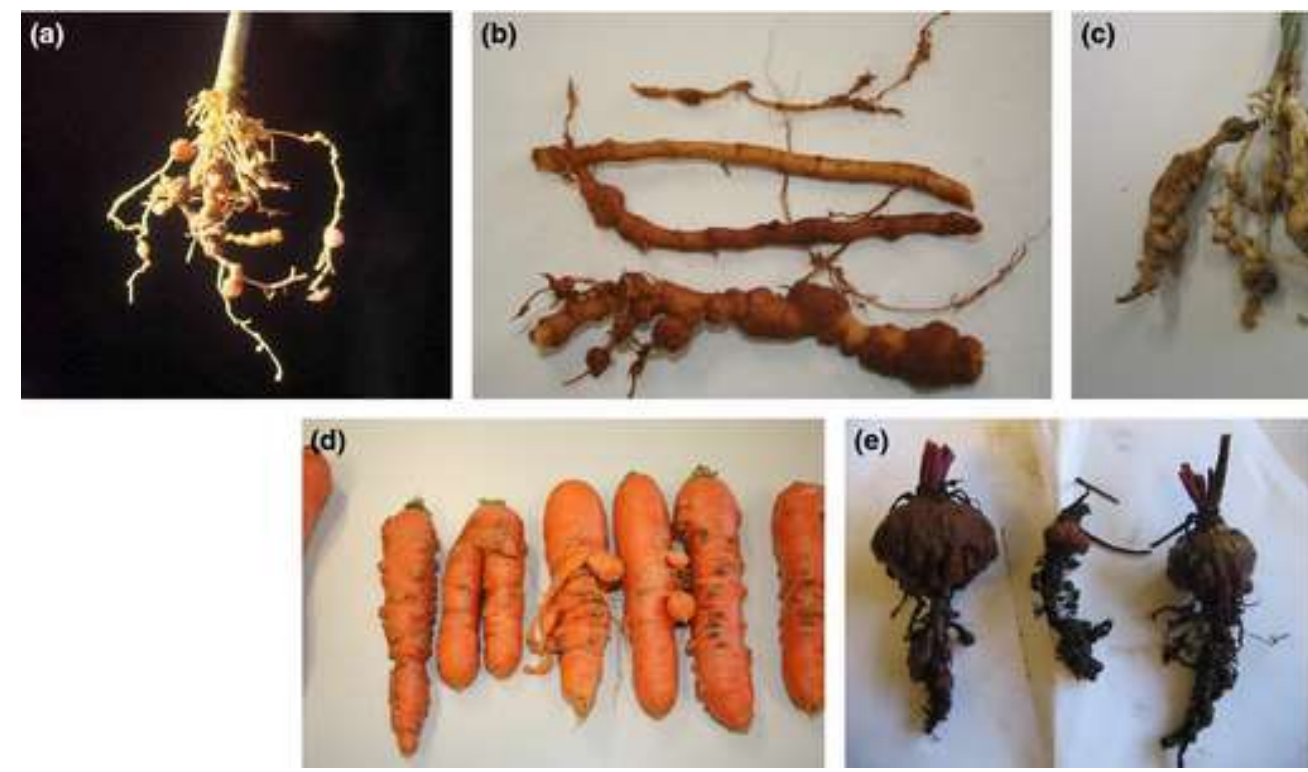

Figure 1. Galls and other symptoms caused by various Meloidogyne species on select crops. (a) Galls on tomato roots caused by Meloidogyne enterolobii. (b) Galls on grenadella roots caused Meloidogyne incognita. (c) Galls on cucumber roots caused by Meloidogyne javanica. (d) Galls and damage symptoms on carrot caused by Meloidogyne arenaria and M. incognita. (e) Galls on beetroot roots caused by M. javanica and M. incognita. Pictures (d) and (e) represent damage caused by Meloidogyne species during co-infection. 
Based on the level of nematode populations, Meloidogyne spp. can cause high levels of crop loss during growth, increase the cost of production through increased fertilizer application and control programmes, and also significantly reduce post-harvest yields (Figure 2). Crop losses of $30 \%$ or more

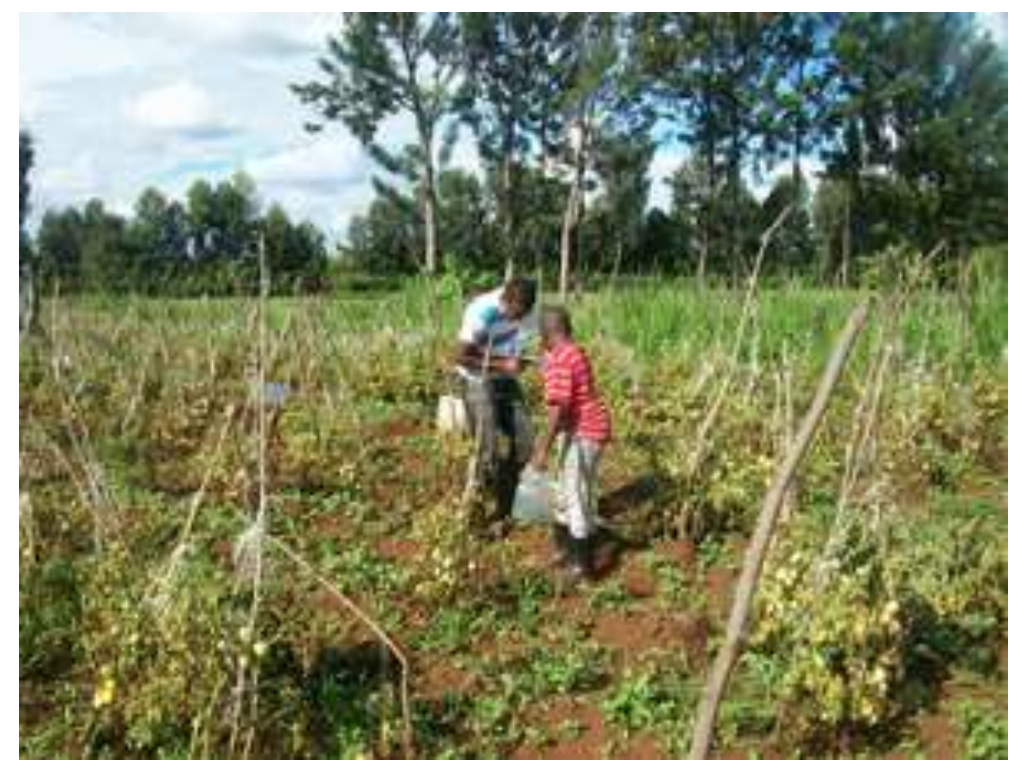

Figure 2. Damage caused by Meloidogyne spp. in a tomato field in Mwea, Kenya.

in tobacco farms in some parts of Tanzania have been reported (Whitehead, 1969). In addition, crop losses of $50 \%$ in pyrethrum flower yields and a decrease in pyrethrin content in Kenya has also been attributed to Meloidogyne spp. infection (IITA, 1981). During surveys carried out by Fourie et al. (2001a) on soy bean in South Africa, Meloidogyne spp. that significantly hamper soybean production were observed in 16 of the 17 different localities sampled by the authors. In South Africa alone, potato production losses associated with plant parasitic nematode species in 1989 were estimated to be $16.7 \%$, accounting for $\$ 7$ Million annually (Keetch, 1989). Speijer and Kajumba (2000) identified Meloidogyne spp. and other plant parasitic nematodes as the phytoparasites that are responsible for $50 \%$ of banana loss in Uganda. Coyne et al. (2006a) also found out that $14.4 \%$ of galling on the yam tubers on sale in Mali were as a result of Meloidogyne spp. infection. Rejection of inferior quality crop produce both locally and internationally, increased scarcity of clean and healthy propagating materials and predisposing of growing crops to secondary infections by other organisms especially soil-borne pathogens are also some of the problems associated with Meloidogyne spp. infection (Powers et al., 2005). For example, interactions between Meloidogyne spp. and pathogens such as Fusarium spp. are well-documented while there may still be many other interactions which are less well-studied (Siddiqui et al., 2010; Mongae et al., 2013). 
The presence of these Meloidogyne spp. populations puts agricultural production in Africa at a significant risk given the fact that most farmers do not have accurate information on the actual Meloidogyne spp. present in their farms (Onkendi and Moleleki, 2013a). This coupled with the ban and restrictions on some of the effective chemical compounds (such as methyl bromide) against a wide range of Meloidogyne spp. and lack of alternative strategies which are effective may greatly contribute to incidents of food crisis across the continent. Meloidogyne fallax and M. chitwoodi are listed as quarantine organisms in Europe as per the EC Directive of 2000/29/EC and EPPO region (Viaene et al., 2007; OEPP/EPPO bulletin, 2009; Wesemael et al., 2011). Furthermore, M. enterolobii is also listed as a quarantine organism across Europe (OEPP/EPPO bulletin, 2011). Therefore this scenario compounds the problems farmers in African countries face while exporting their farm produce especially to the European markets. The presence of these pathogens in their produce leads to rejection at the international markets (Powers et al., 2005). Resistance breaking species such as M. enterolobii may also contribute to a reduction in forest cover which may affect water catchment zones and also access to water in the longrun. This may happen in isolation or in conjunction with highly damaging forestry pathogens. Forest cover cushions various countries from adverse environmental conditions such as floods and drought.

\section{Species identification}

Many African countries have inadequate diagnostic capabilities to carry out reliable pathogen diagnostic services (Ogundiran, 2005). This has led to fragmented data on the presence and distribution of Meloidogyne spp. which has serious implications on various aspects of agriculture. There is the threat of introduction of new and possibly aggressive Meloidogyne spp. to an area, higher cost implications through management strategies that target the wrong organism and loss of revenue due to produce being denied entry into other countries based on the presence of a quarantine organism. Historically, nematologists have relied solely on morphological and morphometrical characters to identify Meloidogyne spp. The earliest use of isozymes as biochemical methods to identify Meloidogyne spp. was published by Esbenshade and Triantaphyllou (1985) and according to Blok and Powers (2009), isozymes are a convenient first stage approach in determining Meloidogyne spp. biodiversity. Antibodies, both polyclonal and monoclonal have been produced for Meloidogyne spp. diagnostics but the use of antibodies is limited to few examples as it has, according to Blok and Powers (2009) been superseded by DNA-based diagnostics (Davies et al, 1996; Tastet et al., 2001). In recent years, identification methods which are DNA-based have gained popularity and this has led to a combination 
of both morphological, biochemical and molecular methods to describe and identify nematodes (Karssen et al., 2004: Castillo et al., 2009).

\section{Morphological and morphometric characteristics}

The use of morphological and morphometric characters was traditionally the most common method used by diagnosticians as the preliminary and routine method of identifying Meloidogyne spp. These methods rely heavily on the shape of body, labial region, stylet length, shape of stylet cone, basal knobs and nature of perineal pattern in female labial region and characteristics of size, stylet length, distance of the dorsal gland orifice (DGO) from the stylet base for males and J2 juveniles (Kleynhans, 1991; Hunt and Handoo, 2009). According to Hunt and Handoo (2009), clear interspecific boundaries that all Meloidogyne spp. diagnostician yearn for are becoming increasingly obscure due to factors such as existence of obscure species and an increasing occurrence of new or emerging species. These authors also cite variable morphometrics, conserved morphology host effects, intraspecific variation, and parthenogenetic mode of reproduction as obscuring factors. This problem is best illustrated by the fact that the existence of what is known as the incognita type perineal pattern is now acknowledged to occur in a number of species (Hunt and Handoo, 2009). Hence, this underscores the importance of an integrated diagnostic approach in identification of Meloidogyne spp. (Landa et al., 2008; Blok and Powers, 2009).

\section{Isozyme phenotypes}

Isozymes are variants of a particular enzyme. Isozyme phenotypes have been used for routine identification of various Meloidogyne spp. in several parts of Africa despite the fact that they are restricted to the adult female stage of development (Esbenshade and Triantaphyllou, 1990; Muturiet al., 2003). The adult female stage is the suitable stage since it is associated with the expression of a given gene product. The procedure is easy and quick to perform and given the fact that reference standards for certain Meloidogyne spp. (usually M. javanica) are used, it is easy to identify various Meloidogyne spp. which are usually common.

The limitations of diagnostic tests based entirely on isozyme phenotypes include lack of capacity to utilize other stages of development (second stage juveniles and eggs) and lack of a wide array of standards to compare results with (Molinari et al., 2005; Wesemael et al., 2011). In some cases, it is difficult to determine and differentiate band sizes between different species during identification. This has necessitated the use of more than one enzyme to resolve this problem. Malate 
dehydrogenase $(\mathrm{mdh})$ is known to separate $M$. hapla from M. incognita, M. arenaria and M. javanica, whereas glutamate dehydrogenase can separate $M$. incognita from $M$. javanica, $M$. arenaria and $M$. hapla (Esbenshade and Triantaphyllou, 1990; Muturi et al., 2003). Due to these limitations, in surveys aimed at the identification of Meloidogyne spp., the use of isozymes can be applied as an initial step of identification.

\section{Molecular-based identification methods}

Molecular-based methods used in nematode diagnostics are usually based on nucleic acid studies. Most of these methods, particularly the DNA-based ones, are known to be robust, sensitive, specific and reliable in detecting and distinguishing various Meloidogyne spp. compared to morphological or biochemical methods (Powers et al., 2005; Berry et al., 2007). Based on this, several molecular methods have been employed to accurately identify various Meloidogyne spp. For the purpose of this review, these will be grouped into gel or sequence-based methods as well other methods that do not strictly fall in either of these categories.

Gel-based molecular diagnostic methods include random amplified polymorphism DNA (RAPD), sequence characterized amplified region markers (SCAR-PCR), restriction fragment length polymorphisms (RFLPs) and amplified fragment length polymorphisms (AFLP). The RAPD method employs short sequence RAPD primers to distinguish several Meloidogyne spp. on the basis of species characteristic patterns. These characteristic patterns can be harnessed to design species-specific markers and/or primers (SCAR-PCR) (Zijlstra, 2000; Fourie et al., 2001b). Using RFLPs, genomic (g) DNA is digested with restriction endonucleases followed by probe hybridisation to generate polymorphisms. AFLPs generate unique fingerprints of gDNA through selective PCR amplification of restriction digested gDNA fragments that have been ligated to specific adaptors. Microsatellites are high tandem repeats of short sequences which are often located in the heterochromatin, centromeric and telomeric regions of the chromosomes. Polymorphisms generated using microsatellites are due to differences in copy numbers or sequence lengths (Mestrovic et al., 2006). The use of microsatellites (satDNA) to discriminate various Meloidogyne spp. has been explored in a number of studies (Castagnone-Sereno et al., 1993; Piotte et al., 1994; Mestrovic et al., 2006). Other gel-based methods previously used for identification of Meloidogyne spp. include RFLP and AFLP (Curran et al., 1986; Williamson et al., 1997; Fargette et al., 2005).

The advantages of gel-based methods are that they are simple to perform and they are not limited to a certain stage of development (Blok and Powers, 2009). Despite being simple, there are 
some challenges, associated with these methods and these include; low sensitivity, poor band visibility in some cases, lack of reproducibility between different laboratories as well as the need to use high amounts of DNA to achieve desired results(Adam et al., 2007; Blok and Powers, 2009). A further challenge, especially in the case of RFLP and AFLP is the need to, at times, use radioactive materials. These challenges are by far not limited to Africa. This is a global problem that would require global cooperation between researchers for cross-validation of samples if these methods are to be used effectively. However, given the stated lack of financial and other resources, this is a particularly bigger challenge for African researchers as validation would incur huge costs of shipping DNA samples across the globe.

Sequenced-based diagnostics rely, not exclusively, on obtaining sequences of specific gene regions and comparing them with reference sequences deposited in public databases. Sequencebased methods include the use of mitochondrial DNA (mtDNA), ribosomal DNA (rDNA) (Blok and Powers, 2009).The mitochondrial DNA (mtDNA) is one of the regions usually targeted for identifying various Meloidogyne spp. (Hyman, 1990; Hugall et al., 1994; Hyman and Whipple, 1996). Multiple copies present in the mitochondrial DNA in each cell offer a ready template for PCR assays and other molecular studies (Brown et al., 1979). The low level of recombination that is associated with the mitochondrial DNA coupled with high rates of evolution provides a unique region that has also been utilized for phylogenetic studies and in studying different Meloidogyne spp. (Blouin, 2002; Blok and Powers, 2009). The cytochrome oxidase subunit I (COI) within the mitochondrial DNA is currently being viewed as a potential gene that can be used in bar coding all Meloidogyne spp. and also in studying evolutionary trends and intra-specific variations within Meloidogyne populations (Powers, 2004; Blok, 2005). Based on this barcoding concept, other studies have suggested the clustering of nematodes into molecular operational taxonomic units (MOTUs) which have individuals with highly similar sequence homology. These sequences are based on a specific gene which may not necessarily be the $\mathrm{CO}$ of the mtDNA (Floyd et al., 2002).

Molecular sequence-based identification can also be based on the ribosomal DNA (rDNA) to identify various Meloidogyne spp. The 18S, 28S (26S), 5.8S coding genes, the internal transcribed spacer (ITS), the external transcribed spacer (ETS) and the intergenic spacer (IGS) regions are usually employed in diagnostics and phylogenetic studies (Blok et al., 1997). The repetitive nature of rDNA provides a better template for PCR work due to more variations among Meloidogyne spp. than other regions such as the D2-D3 (Palomares-Rius et al., 2007). Variations in sequences occur between 
regions of the rDNA that codes for 18S, 28S (26S) and 5.8S. Therefore these repetitions and sequence variations can be exploited for identification of Meloidogyne spp.

The use of sequence based methods coupled with depositing of these sequences into publicly available databases presents huge opportunities for many African researchers for the identification of Meloidogyne spp. The advantage being that comparisons do not require obtaining and shipping voucher specimens or reference DNA from all over the world since the analysis can be done using platforms linked to international databases through the internet. Therefore, this is also a huge benefit to other researchers who may identify new Meloidogyne spp. and may need to compare their unique sequences with those deposited in databases for similar Meloidogyne spp. identified in other countries.

Microarrays, although not yet widely adopted for identification of Meloidogyne spp., are also useful in Meloidogyne spp. diagnostics due to their potential to target various regions simultaneously. The major challenge with microarrays is that they are costly for non-established resource poor laboratories. There are also other global challenges associated with microarrays such as sensitivity and specificity which will need to be properly optimised before they can be widely used (Blok and Powers, 2009).

As molecular technology continue to advance, the entry of real time PCR (qPCR) has significantly improved identification of Meloidogyne spp. This method has increased sensitivity, specificity and simultaneous detection of more than one Meloidogyne spp. can be done within one qPCR assay. Besides this, the method can be performed within a short period due to the fact that there are no post PCR procedures. Apart from detection, qPCR can be used to quantify the amount of nucleic acid present and in genotyping through the generation of high resolution melt curves (HRMC) that are only specific to certain species (Bates et al., 2002; Holterman et al., 2012). To this end, some progress involving different Meloidogyne spp. has been made in trying to use this approach (Zijlstra and Van Hoof, 2006; Berry et al., 2008; De Weerdt et al., 2011; Holterman et al., 2012). All these studies have demonstrated that using qPCR in Meloidogyne spp. studies is specific and efficient.

Overall, gel-based methods for example SCAR-PCR provide a cost friendly and effective method of Meloidogyne spp. delineation. However, since there is a number of emerging Meloidogyne spp., it is difficult to say with certainty that a given method is capable of delineating all the Meloidogyne spp. alone. Several methods which are affordable, accurate, reproducible and widely adopted by other research laboratories should be considered too. 


\section{Management strategies}

The ultimate goal of controlling various Meloidogyne spp. in the soil is to protect the crop from attack, cushion it from being predisposed to secondary infections and achieve maximum crop yield at the end of the growing season at a low cost (Coyne et al., 2006a; Norshie et al., 2011). Pest management strategies which have been adopted in most parts of Africa can be categorized broadly as cultural, biological or chemical. These are either practised singly or in combination to achieve desired results.

\section{Chemical control methods}

Chemical methods of control involve the application of different inorganic formulations to kill or interfere with the reproduction of Meloidogyne spp. in infested soils. In Meloidogyne spp. control programmes, nematicides are usually the most effective method of controlling high levels of Meloidogyne spp. in various farms. Nematicides containing active ingredients of methyl bromide and other harmful compounds have been banned in various parts of the world. Other nematicides which are known to control various Meloidogyne spp. include Fenamiphos, Oxamyl, 1, 3 dichloropropene (1, 3-D), Aldicarb, Dazomet and metam-sodium. Nematicides reduce high populations of various Meloidogyne spp. in the soil though they do not completely eliminate them particularly once the symptoms have started to be noticed (Sirias, 2011). They can be applied either as pre-plant nematicides, fumigants or as contact nematicides (Strajnar and Širca, 2011). Breaking of large lumps of soil, good soil humidity and removing crop remains of the previous season from the soil is very essential for these nematicides to work well.

The disadvantages of using chemical methods to control these Meloidogyne spp. is that, some of them are toxic to humans due to residues in the food chain, they contribute to environmental pollution through the pollution of the ozone layer (such as methyl bromide), they are expensive to small scale farmers and their continued use can lead to some level of resistance to the target nematode species. This resistance can be mainly as a result of mutation given the fact that the phylum Nematoda is associated with high evolution rates (Blouin et al., 1995).

\section{Biological control methods}

Biological methods entail the use of living organisms either in pure cultures or in mixtures to control Meloidogyne spp. Some biological products such as those developed by Pasteuria Inc., and Koppert Biological Systems against certain Meloidogyne spp. have demonstrated significant effect in 
the control of these plant parasitic nematodes. These products are usually developed from microorganisms such as Pasteuria penetrans, Pasteuria hartismeri, Pochonia chlamydosporia, Bacillus firmus, Paecillomyces lilacinus and Trichoderma spp., which attach to the nematode cuticle or parasitize the female eggs therefore killing the nematodes eventually (Kariuki and Dickson, 2007; Bishop et al., 2007). In addition, some studies have also shown another biological strategy where endophytes such as Fusarium oxysporum (F0162) can induce systemic resistance against Meloidogyne spp. in some crops such as tomato (Walters, 2009). Colonization of roots by Fusarium oxysporum (FO162) leads to the accumulation of root exudates in tomato roots which have a repelling effect on M. incognita (Mohamed, 2010).

Soil amendment procedures involving the application of organic materials (such as farm manure and extracts from Marigold (Tagetes species) to release toxic compounds that can kill plant parasitic nematodes have also been explored as a form of biological control (Mcsorley and Duncan, 1995). Antagonistic bacteria such as Pseudomonas aeruginosa in these decomposing organic materials either act as competitors or release metabolic toxins which may change the nature of root exudates (aimed at reducing the population of Meloidogyne spp. colonizing the roots) or kill various Meloidogyne spp. To achieve better results from soil amendments, organic materials should be applied at high rates to have a significant effect on nematode populations (Putten et al., 2006). In general, the use of organic material is not only cheap but also improves the efficiency of these antagonistic bacteria by offering them ready nutrients which are essential for their growth and survival.

\section{Cultural control methods}

Cultural practices include the development and use of resistant crop cultivars, planting clean planting materials, intercropping, crop rotation and cleaning of farm implements (Brown et al., 2006). Many of these practices have been used successfully in various parts of Africa to reduce the spread of Meloidogyne spp. in different crop fields for many years. However, the cost and availability of clean planting material can at times be a hindrance to many small scale growers. Furthermore, the limitation of employing crop rotation as a control strategy in commercial farms is that it is not economically feasible due to economic losses which may be incurred during the fallow periods and also in trying to establish a new crop in large scale as the previous one. Growth challenges associated with human population also make crop rotation virtually impractical in certain parts of the continent. Prior to use of methods such as crop rotation, the identity of Meloidogyne spp. should be understood, its host range and also the cropping history of the field evaluated. This is critical in decision making to avoid indiscriminate use of nematicides and also scale down management costs. 
Physical methods such as heat treatment and solarization of the soil before planting can be combined with cultural methods for effective control of various Meloidogyne spp. (loannou, 2000). Solarization of nursery soil up to $40 \mathrm{~cm}$ for a period of three weeks has been found effective in reducing egg infectivity (Nico et al., 2003).

\section{Resistant cultivars}

The basis of using resistant cultivars to control Meloidogyne spp. relies on knowing exactly which species is being targeted. Several studies are underway to develop crops with resistance genes against various Meloidogyne spp. (Norshie et al., 2011). There are certain cases of known resistant crops as in the case of tomatoes (due to the Mi-1 gene) and wild potato (Solanum bulbocastunum). Initially, the resistance gene (Rmc-1) located on chromosome 11 of wild potatoes was found to confer resistance against M. chitwoodi and other Meloidogyne spp. such as M. fallax and M. hapla (Gebhardt and Valkonen, 2001; Brown et al., 2006). But with the entry of resistance breaking Meloidogyne spp., some of the crops have been rendered susceptible (Janssen et al., 1998; Brown et al., 2009; Kiewnick et al., 2009). Future prospects of using resistant cultivars to manage Meloidogyne spp. require more research. Norshie et al. (2011), recently showed that certain potato lines are capable of resisting $M$. chitwoodi partially during infection. With the enormous amount of information being generated from the expressed sequence tags (ESTs), genome, transcriptome and proteomic sequences and attempts to introduce genes into plants to code for protein inhibitors such as chitinases, collagenases, cytotoxins, lectins and monoclonal antibodies against plant parasitic nematodes, it is hoped that an increase in transgenic crops with resistance to Meloidogyne spp. can be anticipated in the future (Fuller et al., 2008).

Resistant cultivars will not only reduce the cost of production but also safeguard the environment against pollution from chemical residues associated with nematicides. Resistance of various crops to Meloidogyne spp. infection is important since a resistant crop can allow little or no Meloidogyne spp. reproduction thus providing a better way of controlling nematodes in a crop field (Norshie et al., 2011). In order to achieve promising results with the use of resistant cultivars, there is need to constantly carry out accurate species identification and surveillance. It is also important to educate growers to try and contain resistance breaking Meloidogyne spp. such as M. enterolobii where they have been detected. Ultimately the cost and availability of resistant genotypes will be a huge influencing factor on whether these benefits will trickle down to small scale growers in Africa. 


\section{Concluding remarks}

The recent identification of 'emerging' highly damaging and resistant Meloidogyne spp. in certain parts of Africa poses a considerable challenge to formulation of effective management strategies. Lack of accurate and current data on various Meloidogyne spp. present in each part of the continent and the polyphagous nature of these pathogens also poses a greater risk on the future of food production in Africa.

To adequately address these emerging and other Meloidogyne spp., it is imperative that resources are harnessed to drive more research aimed at assessing and understanding the species identity, genetic diversity, population structure, parasitism mechanisms and the overall threat posed by them (Fargette et al., 2010). Therefore there is need to embrace modern technology in conjunction with classical methods while carrying out Meloidogyne spp. identification.

It is imperative to have platforms that will allow those involved in research projects focussing on Meloidogyne spp. identification to share information with other projects targeting other phytoparasitic nematodes of economic importance. This is vital particularly in understanding the parasitism mode of these pathogens since they share some traits (Curtis, 2007). The training of more scientists in the field of plant parasitic nematodes and molecular biology should also be a key priority to various agricultural stakeholders if at all food sustainability and income generation is to be achieved (Barker et al., 1994; Barker, 2003).

To effectively manage these highly damaging pathogens and other Meloidogyne spp., application of biological, cultural and chemical methods should be done in line with integrated pest management (IPM) practices. This should be preceded with a thorough survey of farms in context and an accurate diagnosis of Meloidogyne spp. present. Molecular based methods of diagnosis should be used together with classical methods for accurate identification (Oliveira et al., 2011). This will lead to gradual management of Meloidogyne spp. and finally reduction in the high damage that they cause on various crops. This strategy will eventually benefit growers and avoid high costs of production.

With the phasing out of various effective nematicides such as methyl bromide, the search for effective and environmental friendly alternative methods should be pursued. At the same time more robust diagnostic techniques should be adopted to correctly identify and avoid further spread of the highly damaging, resistance breaking and emerging Meloidogyne spp. Growers should also be 
educated on proper phytosanitary procedures to avert the introduction of Meloidogyne spp. into their farms.

\section{Acknowledgement}

Authors will wish to thank the Nematology Unit, ARC-PPRI for the use of data from the South African Plant-Parasitic Nematode Survey (SAPPNS) database.

\section{References}

Abad, P., Gouzy, J., Aury, M-J., \& Castagnone-Sereno, P., et al. (2008). Genome sequence of the metazoan plant-parasitic nematode Meloidogyne incognita. Nature Biotechnology 26, 909-915.

Adam, M. A. M., Phillips, M. S., \& Blok, V. C. (2007). Molecular diagnostic key for identification of single juveniles of seven common economically important species of root-knot nematode (Meloidogyne spp.).Plant Pathology 56,190-197.

Barker, K. R. (2003). Perspectives on plant and soil nematology. Annual Review of Phytopathology 41, 125.

Barker, K. R., Hussey, R. S., Krusberg, L. R., Bird, G. W., Dunn, R. A., Ferris, H., et al. (1994). Plant and soil nematodes - societal impact and focus for the future. Journal of Nematology 26, 127-137.

Bates, J. A., Taylor, E. J. A., Gans, P. T., \& Thomas, J. E. (2002). Determination of relative proportions of Globodera species in mixed populations of potato cyst nematodes using PCR product melting peak analysis. Molecular Plant Pathology 3, 153-161.

Berry, S. D., Fargette, M., Spaull, V. M., Morand, S., \& Cadet, P. (2008). Detection and quantification of root-knot nematode (Meloidogyne javanica), lesion nematode (Pratylenchus zeae) and dagger nematode (Xiphinema elongatum) parasites of sugarcane using real-time PCR. Molecular and Cellular Probes 22, 168-76.

Berry, S. D., Fargette, M., Morand, S., \& Cadet., P. (2007). Reliability of PCR-based techniques for detection and discrimination of plant-parasitic nematodes of sugarcane. Nematology 9, 499-514. 
Bishop, A. H., Gowen, S. R., Pembroke, B., \& Trotter. J. R. (2007). Morphological and molecular characteristics of a new species of Pasteuria parasitic on Meloidogyne ardenensis. Journal of Invertebrate Pathology 96, 28-33.

Blok, V. C., Phillips, M. S., \& Fargette, M. (1997). Comparison of sequences from the ribosomal DNA intergenic region of Meloidogyne mayaguensis and other major tropical root-knot nematodes. Journal of Nematology 29, 16-22.

Blok, V. C. (2005). Achievements in and future prospects for molecular diagnostics of plant parasitic nematodes. Canadian Journal of Plant Pathology 27, 176-185.

Blok, V. C., \& Powers, T. O. (2009). Biochemical and molecular identification. In R. N Perry, M. Moens, \& J. L. Starr (eds.), Root-knot nematodes (pp.98-118). CAB International. Nosworthy Way, Wallingford, Oxfordshire OX10 8DE, UK.

Blouin, M.S. (2002). Molecular prospecting for cryptic species of nematodes: mitochondrial DNA versus internal transcribed spacer. International Journal for Parasitology 32, 527-531.

Blouin, M. S., Yowell, C. A., Courtney, C. H., \&Dame., J. B.(1995). Host movement and the genetic structure of populations of parasitic nematodes. Genetics 141, 1007- 1014.

Brown, C. R., Mojtahedi, H., Zhang, L. H., and Riga, E. (2009). Independent resistant reactions expressed in root and tuber of potato breeding lines with introgressed resistance to Meloidogyne chitwoodi. Phytopathology 99, 1085-1089.

Brown, C. R., Mojtahedi, H., James, S., Novy, R. G., \& Love, S. (2006). Development and evaluation of potato breeding lines with introgressed resistance to Columbia root-knot nematode (Meloidogyne chitwoodi). American Journal of Potato Research 83, 1-8.

Brown, W. M., George, M. J., \& Wilson, A. C. (1979). Rapid evolution of animal mitochondrial DNA. National Academy of Science, USA 76, 1967-1971.

CABI (2005). Meloidogyne ethiopica. In Distribution maps of plant diseases. Map No. 962.

CABI (2003). Meloidogyne arenaria. In Distribution maps of plant diseases. Map No. 900.

CABI (2002b). Meloidogyne incognita. In Distribution maps of plant diseases. Map №. 854. 
CABI (2002a). Meloidogyne hapla. In Distribution maps of plant diseases. Map №. 853.

Castagnone-Sereno, P., Semblat, J. Philippe, \& Abad, P. (1993). A new Alul satellite DNA in the root-knot nematode Meloidogyne fallax: relationships with satellites from the sympatric species $M$. hapla and $M$. chitwoodi. Molecular Biology and Evolution 15, 1115-1122.

Castillo, P., Vovlas, N., Troccoli, A., Liebanas, G., Rius, J. E. P., \& Landa, B. B. (2009). A new root-knot nematode, Meloidogyne silvestris n. sp. (Nematoda: Meloidogynidae), parasitizing European holly in northern Spain. Plant Pathology 58, 606-619.

Carneiro, R. M. D. G., Carneiro, R. G., Abrantes, I. M. O., Santos, M. S.N., \& Almeida, M. R. A. (1996). Meloidogyne paranaensis $\mathrm{n}$. sp. (Nemata: Meloidogynidae), a root-knot nematode parasitizing coffee in Brazil. Journal of Nematology 28,177-189.

Coyne, D. L., Tchabi, A., Baimey, H., Labuschagne, N., \& Rotifa, I. (2006a). Distribution and prevalence of nematodes (Scutellonema bradys and Meloidogyne spp.) on marketed yam (Dioscorea spp.) in West Africa. Field Crops Research 96, 142-150.

Coyne, D.L., Toko, M., Andrade, M., Hanna, R., Sitole, A., Kagoda, F., Al Banna, L., \& Marais, M. (2006b). Meloidogyne spp. and associated galling and damage on cassava in Kenya and Mozambique. African Plant Protection 12, 35-36.

Curran, J., McClure, M. A., \& Webster, J. M. (1986). Genotypic differentiation of Meloidogyne populations by detection of restriction fragment length difference in total DNA. Journal of Nematology 18, 83-86.

Curtis, R. H. C. (2007). Plant parasitic nematode proteins and the host-parasite interaction. Briefings in Functional Genomics and Proteomics 6, 50-58.

Davies, K.G., Curtis, R.H. \& Evans, K. (1996). Serologically, based diagnostic and quantification tests for nematodes. Pesticide Science 47, 81-87.

De Grisse, A. (1960). Meloidogyne kikuyensis n. sp., a parasite of kikuyu grass (Pennisetum clandestinum) in Kenya. Nematologica 5, 303-308.

De Waele, D., \& Elsen, A. (2007). Challenges in tropical plant nematology. Annual Review of Phytopathology 45, 457-485. 
De Weerdt, M., Kox, L., Waeyenberge, L., Viaene, N., \& Zijlstra, C. (2011). A real-time PCR assay to identify Meloidogyne minor. Journal of Phytopathology 159, 80-84.

Eisenback, J.D. (1997). Root-knot nematode taxonomic database. CAB International, Wallingford, UK, CDROM.

Elling, A. A. (2013). Major emerging problems with minor Meloidogyne species. Phytopathology 103, 10921102.

Elmiligy, E. I. A. (1968). Three new species of the genus Meloidogyne Goeldi, 1887 (Nematoda: Heteroderidae). Nematropica 14, 577-590.

Esbenshade, P. R., \&Triantaphyllou, A. C. (1990). Isozyme phenotypes for the identification of Meloidogyne species. Journal of Nematology 22, 10-15.

Esbenshade, P.R. \&Triantaphyllou, A. C. (1985). Use of enzyme phenotypes for identification of Meloidogyne species. Journal of Nematology 17, 6-20.

Fargette, M., Berthier, K., Richaud, M., Lollier, V., Franck, P., Hernandez, A., Frutos, R. (2010). Crosses prior to parthenogenesis explain the current genetic diversity of tropical plant-parasitic Meloidogyne species (Nematoda: Tylenchida). Infection, Genetics and Evolution 10, 807-814.

Fargette, M., Lollier, V., Phillips, M., Blok, V., \& Frutos, R. (2005). AFLP analysis of the genetic diversity of Meloidogyne chitwoodi and M. fallax, major agricultural pests. C. R Biologies 328, 455-462.

Floyd, R., Abebe, E., Papert, A., \& Blaxter, M. (2002). Molecular barcodes for soil nematode identification. Molecular Ecology 11, 839-50.

Fourie, H., McDonald, A. H., \& Loots, G. C. (2001a). Plant-parasitic nematodes in field crops in South Africa. 6. Soybean. Nematology 3, 447-454.

Fourie, H., Zijlstra, C., \& McDonald, A.H. (2001b). Identification of root-knot nematode species occurring in South Africa using SCAR-PCR technique. Nematology 3, 675-689.

Fuller, V. L., Lilley, C. J., \& Urwin, P. E. (2008). Nematode resistance. New Phytologist 180, 27-44. 
Gebhardt, C., \& Valkonen, J. P. T. (2001). Organization of genes controlling disease resistance in the potato genome. Annual Review of Phytopathology 39, 79-102.

Holterman, M. M., Oggenfuss, M., Frey, J. E., \&Kiewnick, S. (2012). Evaluation of high-resolution melting curve analysis as a tool for root-knot nematode diagnostics. Phytopathology 160, 59-66.

Hugall, A., Moritz, C., Stanton, J., \& Wolstenholme, D. R. (1994). Low, but strongly structured mitochondrial DNA diversity in root-knot nematodes (Meloidogyne). Genetics 136, 903-912.

Hyman, B. C., \& Whipple, L. E. (1996). Application of mitochondrial DNA polymorphisms to Meloidogyne molecular population biology. Journal of Nematology 28, 268-276.

Hyman, B. C. (1990). Molecular diagnosis of Meloidogyne species. Journal of Nematology 22, 24-30.

Hunt, D.J.,\& Handoo, Z.A. (2009). Taxonomy, identification and principal species. In R. N Perry, M. Moens\& J. L. Starr (eds.), Root-knot nematodes (pp 55-97). CAB International, Wallingford, UK.

IITA. (1981). Proceedings of the third research planning conference on root-knot nematodes, Meloidogyne spp. International Meloidogyne Project (pp 1-286).

loannou, N. (2000). Soil solarization as a substitute for methyl bromide fumigation in greenhouse tomato production in Cyprus. Phytoparasitica 28, 248-256.

Janssen, G. J. W., Scholten, O. E., Norel, A. V., \& Hoogendoorn, C. J. (1998). Selection of virulence in Meloidogyne chitwoodi to resistance in the wild potato Solanum fendleri. European Journal of Plant Pathology 104, 645-651.

Jones, J. T., Haegeman, A., Danchin, E. G. J., Gaur, H. S., Helder, J., Jones, M. G. K., et al. (2013). Top 10 plant-parasitic nematodes in molecular plant pathology. Molecular Plant Pathology 14, 946-961.

Jones, R. (2005). Nematological myths IV: how serious a threat are the new nematode pests of potatoes? Chips IV, 1-2.

Karssen, G., Bolk, R.J., Van Aelst, A.C., Van den Beld, I., Kox, L.F.F., Korthals, G., Molendijk, L., Zijlstra, C., Van Hoof, R.\& Cook, R. (2004). Description of Meloidogyne minor n. sp. (Nematoda: Meloidogynidae), a root-knot nematode associated with yellow patch disease in golf courses. Nematology 6, 59-72. 
Kariuki, G. M., \& Dickson, D. W. (2007). Transfer and development of Pasteuria penestrans. Journal of Nematology 39, 55-61.

Keetch, D.P. (1989). A perspective of plant nematology in South Africa. South African Journal of Science 85, 506-508.

Kiewnick, S., Dessimoz, M., \& Franck, L. (2009). Effects of the Mi-1 and the N root-knot resistance gene on infection and reproduction of Meloidogyne enterolobii on tomato and pepper cultivars. Journal of Nematology 41, 134-139.

Kleynhans, K.P. N. (1991). The root-knot nematodes of South Africa. Technical Communication No 231. Department of Agricultural Development, South Africa.

Kleynhans, K. P. N., Van den Berg, E., Swart, A., Marais, M. \& Buckley, N. H. (1996). Plant nematodes in South Africa. Plant Protection Research Institute Handbook No. 8. ARC-Plant Protection Research Institute, Pretoria.

Kwerepe, B. C.,\& Labuschagne, N. (2004). Screening of Bambara groundnut landraces for resistance/tolerance to Meloidogyne incognita race 2. African Plant Protection 10, 35-41.

Landa, B. B., Rius, J. E. P., Vovlas, N., Carneiro, R. M. D. G., Maleita, C. M. N., Abrantes, I. M. D. O., Castillo, P. (2008). Molecular characterization of Meloidogyne hispanica (Nematoda, Meloidogynidae) by phylogenetic analysis of genes within the rDNA in Meloidogyne spp. Plant Disease 92, 1104-1110.

Lordello, R. R. A., \&Fazuoli, L. C. (1980). Meloidogyne decalineata in coffee roots from Sao Tome Island (Africa). Revista de Agricultura, Piracicaba, Brazil 55, pp.283.

Marais, M. (2012). Meloidogyne enterolobii (= Meloidogyne mayaguensis): 'n Gevalle studie van 'n plant parasitiese nematode. Proceedings of the year Symposium of the Biological Sciences Division of the SA Academy of Arts and Science, North West University, Potchefstroom. October 2012.

Mcsorley, R., \& Duncan, L. W. (1995). Economic thresholds and nematode management. Advances in Plant Pathology 11, 147-162.

Mestrovic, N., Castagnone-Sereno, P., \& Plohl, M. (2006). Interplay of selective pressure and stochastic events directs evolution of the MEL172 satellite DNA library in root-knot nematodes. Molecular Biology and Evolution 23, 2316-2325. 
Moens, M., Perry, R.N., \& Starr, J.L. (2009). Meloidogyne species - a diverse group of novel and important plant parasites. In R. N Perry, M. Moens\& J. L. Starr (eds.), Root-knot nematodes (pp.1-17). CAB International, Wallingford, UK.

Molinari, S., Lamberti, F., Crozzoli, R., Sharma, S. B., \& Portales, L. S. (2005). Isozyme patterns of exotic Meloidogyne spp. populations. Nematologia Meditteranea 33, 61-65.

Mohamed, S. (2010).Biological, chemical and molecular studies on the systemic induced resistance in tomato against Meloidogyne incognita caused by the endophytic Fusarium oxysporum, Fo162. Institute of Crop Science and Resource Conservation, Faculty of Agriculture, University of Bonn, PhD thesis.

Mongae, A., Kubheka, G. C., Moleleki, N., \& Moleleki, L. N. (2013).The use of fluorescent reporter protein tagging to study the interaction between root-knot nematodes and soft rot Enterobacteriaceae. Letters in Applied Microbiology 56, 258-263.

Muturi, J., Gichuki, C., Waceke, J. W., \& Runo, S. M. (2003).Use of isozyme phenotypes to characterize the major root knot nematodes (Meloidogyne spp.) parasitizing indigenous leafy vegetables in Kisii. In "Transforming Agriculture for improved livelihoods through Agricultural Product Value Chains: the Proceedings of the $12^{\text {th }}$ KARI Biennial Scientific Conference." 8-12 th November, 2010, Nairobi, Kenya pp. 605-612.

Nico, A. I., Jimenez-Diaz, R. M., \& Castillo, P. (2003). Solarization of soil in piles for the control of Meloidogyne incognita in olive nurseries in southern Spain. Plant Pathology 52, 770-778.

Norshie, P. M., Been, T. H., \& Schomaker, C. H. (2011). Estimation of partial resistance in potato genotypes against Meloidogyne chitwoodi. Nematology 13, 447-489.

OEPP/EPPO bulletin. (2009). Meloidogyne chitwoodi and Meloidogyne fallax. OEPP/EPPO bulletin.

OEPP/EPPO bulletin.(2011). Meloidogyne enterolobii. OEPP/EPPO Bulletin, 41, 329-339.

Ogundiran, T. O. (2005). Africa must come on board the genomics bandwagon. Genomics, Society and Policy 1, 66-77.

Oliveira de Gonçalves, C. M., Monteiro, R. A., \& Blok, V. C. (2011). Morphological and molecular diagnostics for plant-parasitic nematodes: working together to get the identification done. Tropical Plant Pathology $36,65-73$. 
Onkendi, E. M., \& Moleleki, L. N. (2013a). Distribution and genetic diversity of root-knot nematodes (Meloidogyne spp.) in potatoes from South Africa. Plant Pathology 62, 1184-1192.

Onkendi, E. M., \&Moleleki, L. N. (2013b). Detection of Meloidogyne enterolobii in potatoes in South Africa and phylogenetic analysis based on intergenic region and the mitochondrial DNA sequences. European Journal of Plant Pathology 136, 1-5.

Palomares- Rius J. E., Vovlas, N., Troccoli, G., Landa, B. B., \& Castillo, P. (2007). A new root-knot nematode parasitizing sea rocket from Spanish Mediterranean coastal dunes: Meloidogyne dunensis n. sp. (Nematoda: Meloidogynidae). Journal of Nematology 39, 190-202.

Piotte, C., Castagnone-Sereno, P., Bongiovanni, M., Dalmasso, A., \& Abad, P, (1994). Analysis of satDNA from M. hapla and its use as a diagnostic probe. Phytopathology $85,458-462$.

Powers, T. O., Mullin, P. G., Harris, T. S., Sutton, L. A., \& Higgins, R. S. (2005). Incorporating molecular identification of Meloidogyne spp. into a large-scale regional nematode survey. Journal of Nematology $37,226-235$.

Powers, T. (2004). Nematode molecular diagnostics: from bands to barcodes. Annual Review of Phytopathology 42, 367-383.

Putten, W. H. V. D., Cook, R., Costa, S., Davies, K. G., Fargette, M, Freitas, H., et al. (2006). Nematode interactions in nature: models for sustainable control of nematode pests of crop plants? Advances in Agronomy 89, 227-260.

Rammah, A.,\& Hirschmann, H. (1990). Meloidogyne morocciensis n. sp. (Meloidogyninae), a root-knot nematode from Morocco. Journal of Nematology 22, 279-291.

Siddiqui, Z. A., Nesha, R., Singh, N. and Alam, S. (2010). Interactions of plant-parasitic nematodes and plant pathogenic bacteria in bacteria. In: Bacteria in Agrobiology: Plant Probiotics ed. Maheshwari, D.K. pp 251-257. Berlin Heidelberg: Springer-Verlag.

Sirias, H. C. I. (2011). Root-knot nematodes and coffee in Nicaragua: management systems, species identification and genetic diversity, Plant Breeding. Swedish University of Agricultural Sciences. PhD thesis. 
Spaull, V. W. (1977). Meloidogyne propora n.sp. (Nematoda: Meloidogynidae) from Aldabra Atoll, Western Indian Ocean, with a note on M. javanica (Treub). Nematologica 23, 177-186.

Speijer, P. R., \& Kajumba, C. (2000). Yield loss from plant parasitic nematodes in East African highland banana (Musa spp. AAA). Acta Horticulturae 540, 453-459.

Strajnar, P., \& Širca, S. (2011). The effect of some insecticides, natural compounds and tomato cv. Venezia with Mi gene on the nematode Meloidogyne ethiopica (Nematoda) reproduction. Acta Agriculturae Slovenica 97, 5-10.

Tastet, C., Val, F., Lesage, M., Renault, L., Marché, L., Bossis, M. \& Mugniéry, D. (2001). Application of a putative fatty-acid binding protein to discriminate serologically the two European quarantine root-knot nematodes, Meloidogyne chitwoodi and M. fallax, from other Meloidogyne species. European Journal of Plant Pathology 107, 821-832.

Viane, N. V., Mahieu, T. M., \& De la Pena, E. (2007). Distribution of Meloidogyne chitwoodi in potato tubers and comparison of extraction methods. Nematology 9, 143-150.

Walters, D. R. (2009). Are plants in the field already induced? Implications for practical disease control. Crop Protection 28, 459-465.

Wesemael, W. M. L., Viaene, N., \&Moens, M. (2011). Root-knot nematodes (Meloidogyne spp.) in Europe. Nematology 13, 3-16.

Williamson, V. M., Cawell-Chen, E. P., Westerdahl, B. B., Wu, F. F., \& Caryl, G. (1997). A PCR assay to identify and distinguish single juveniles of Meloidogyne hapla and M. chitwoodi. Nematology 29, 9-15.

Whitehead, A. G. (1969). The distribution of root-knot nematodes (Meloidogyne spp.) in tropical Africa. Nematologica 15, 315-333.

Whitehead, A. G. (1968). Taxonomy of Meloidogyne (Nematoda: Heteroderidae) with descriptions of four new species. Transactions of the Zoological Society of London 31, 263-401.

Whitehead, A. G. (1959). The root-knot nematodes of East Africa Meloidogyne africana n. sp., a parasite of arabica coffee (Coffea arabica L.).Nematologica 4, 272-278. 
Whitehead, A. G., and Kariuki.L. (1960). Root-knot nematode surveys of cultivated areas in East Africa. East African Agriculture and Forestry Journal 26, 87-91.

Yang, B., and Eisenback, J. D. (1986). Meloidogyne enterolobii n. sp. (Meloidogynidae), a root-knot nematode parasitizing pacara earpod tree in China. Journal of Nematology 15, 381-391.

Zijlstra, C. (2000). Identification of Meloidogyne chitwoodi, M. fallax and M. hapla based on SCAR-PCR: a powerful way of enabling reliable identification of populations or individuals that share common traits. European Journal of Plant Pathology 106, 283-290.

Zijlstra, C., \& Van Hoof, R. A. (2006). A multiplex real-time polymerase chain reaction (TaqMan) assay for the simultaneous detection of Meloidogyne chitwoodi and M. fallax. Phytopathology 96, 1255-1262.

Zijlstra, C., Donkers-Venne, D. T. H. M., \& Fargette, M. (2000). Identification of Meloidogyne incognita, M. javanica and M. arenaria using sequences characterised amplified region (SCAR) based PCR assay. Nematology 2, 847-853. 